\title{
THE ANALYSIS OF REAL ESTATE SALES AND URBAN DATA: THE IMPACT ON RESOURCE ALLOCATION
}

\author{
William M. Shenkel and Allan S. Eidson
}

\author{
University of Georgia
}

Much of the data for urban analysis is based on census data as supplemented by special planning surveys. With respect to real estate information, much of this data tends to be out of date or it is often based on imperfect building permit data, new subdivision records, and limited property taxinformation. For the most part real estate sales data remain unused or usedin a limited way. To a great extent real estate sales data appear to be incompletely applied because of (1) the presumed high cost of gathering data, (2) the belief that publicly recorded data are unreliable, and (3) the general impression that real estate prices are private and that open price knowledge should be avoided.

Briefly, this paper shows that real estate data a re generally available at an economic cost, that statistical routines may be substituted for expensive field surveys, and that sales data may be merged with other data bases for planning and related purposes.

Before defending this general thesis, first, let me state that the project described here covers the analysis of almost 24,000 real estate sales recorded in 1968 for a high urbangrowth area: Broward County (Fort Lauderdale), Florida. The data were subjected to computer processing as part of a newly developed computed valuation system. In this respect it should be noted that the sales data base constitutes a necessary element in the computer valuationsystem. Let me also add that it appears technically and economically feasible to develop a uniform system of valuation and to provide an annual updating of tax valuation; thereby removing a common complaint over the maladministration of the property tax.

So that the data may be more easily interpreted, a brief comment on how sales data are used for property tax purposes will prove helpful in interpreting later conclusions. Construction of the data base begins by card punching commonly recorded sales data, i.e., the date of sale, the name of the buyer and the seller, the type of sales instrument, the value of state revenue stamps, and the legal description.

The next most important step required identification of each property sale by its property tax number. That is, every property entered on the tax roll has a unique number. By entering this number for every real estate transaction, sales data may be merged with property tax data. Hence sales data a re automatically associated with assessed values and property characteristics that are card punched as part of the property tax record system. Note that in this procedure, the computer programs are the only new element added to this system. Costly field surveys are avoided.

Essentially the data base is constructed from a merger of sales and peoperty tax records. From these data are constructed stratified sales assessment ratios that show the relative uniformity of the property tax among several categories. In addition the sales data base is manipulated to show growth trends, neighborhood analysis, and other series especially important to evaluating housing and other urban trends. From this step, samples are drawn for a series of multiple regression models that a re used to calculate property values directly for discrete neighborhoods and for different property types. While a property tax valuation system covers other important steps, 
i. e., computer terminal programs and more complex income models, the manipulation of the sales data base constitutes the single most important element for peoperty tax purposes and, it is suggested, for the allocation of urban resources.

\section{The Relationship Between Stratified Sales Data and Growth Models}

Table I indicates the classification of real property sales over a calendaryearby selected propertytypes. In itself the table, for resource allocation purposes, has little to offer. Yet by interpreting this table with other data and by subjecting each property classification to more intensive analysis, the range of data applications is considerably extended. In this instance, note that single family dwelling sales represent 61 percent of all sales transactions. Moreover, in this distribution, annual data reveal that multiple family, cooperative, and condominium housing absorb 22.3 percent of all real estate transactions. As data are recorded for succeeding years and converted to housing units, significant (and current) changes in the housing market could be readily determined.

Though not shown in Table I, these data are further classified by other distributions. For example, multiple family dwellings of more than twentyfour apartment units each, representing forty-eight cases, and the number of duplexes may be easily sorted from the data at hand. Similarly, condominiums were further subdivided between low-rise and high-rise units. Interpreted with other data, such a classification helps predict the absorption rate on fairly current basis. Housing density estimates may be taken from these distributions. In this regard, sales data are believed superior to alte rnative data bases.

TABLE I - THE CLASSIFICATION OF REAL PROPERTY SALES BY PROPERTY TYPE SHOWING SELECTED ASSESSMENT DATA: 1968

\begin{tabular}{|c|c|c|c|c|}
\hline Type of Property & $\begin{array}{c}\text { Number } \\
\text { of } \\
\text { Sales } \\
\end{array}$ & $\begin{array}{c}\text { Percent of } \\
\text { Total } \\
\text { Number }\end{array}$ & $\begin{array}{c}\text { Average } \\
\text { Assessment } \\
\text { Ratio }\end{array}$ & $\begin{array}{c}\text { Mean } \\
\text { Deviation }\end{array}$ \\
\hline $\begin{array}{l}\text { Single Family } \\
\text { Dwellings }\end{array}$ & 14,061 & 61.1 & 79.5 & 12.9 \\
\hline $\begin{array}{l}\text { Multiple Family } \\
\text { Dwellings and } \\
\text { Duplexes }\end{array}$ & 1,270 & 5.3 & 77.8 & 17.2 \\
\hline Cooperatives & 515 & 2.2 & n. a & n. a \\
\hline Condominiums & 3,520 & 14.8 & n. a & n. a \\
\hline Motels & 26 & $*$ & 70.5 & 14.9 \\
\hline Retail Buildings & 120 & .5 & 91.1 & 37.2 \\
\hline Office Buildings & 39 & $*$ & 105.5 & 45.0 \\
\hline Industrial Buildings & 171 & .7 & 92.5 & 36.8 \\
\hline Other Properties $* *$ & 3,621 & 15.1 & 77.0 & 20.1 \\
\hline Total & 23,883 & 99.7 & 78.6 & 15.5 \\
\hline
\end{tabular}

*An amount less than .05 percent.

**Vacant land and other unclassified properties. 
For more sophisticated analysis, especially studies directed to the impact of the property tax, sales data constitutes the best possible data source. Note from Table I that retail and commercial buildings (with the exception of hotels) are assessed at a relatively higher average percentage of the sales price than multiple and single family dwellings. It also follows that single family dwellings, relatively, tend to be the most accurately, uniformly assessed property type relative to the income and nonresidential properties.

Table II reveals condominium sales stratified by sales value intervals. The same distribution of sales is also printed for some twelve other property types. Again in planning for urban resource allocation, namely local housing subsidies, such a table has considerable utility. For instance, sales value interval tables (for housing) show the current market demand that is being served by the private sector. Table II suggests that a considerable share of condominium units were probably directed to retirement buyers in relatively low or middle incomes. For example, condominiums sold between $\$ 10,000$ to $\$ 18,000$ absorbed some 56.6 percent of total concominium sales in 1968. By comparing these data with 1969 and later series, the urban planner has a much stronger basis for supporting proposed master plans and local housing programs. Remember, too, that these transactions, classified by value groups, may be identified by location, by low-rise and high-rise units, and similar stratifications.

There is one further point. Note that Table II indicates that nine transactions apparently sold between $\$ 1,001$ to $\$ 6,000$. Their average assessment ratio, 146.6 percent--in the light of succeeding data--strongly indicates that these sales were underreported or represent other data errors. A listing of sales price per square foot (called for in other subroutines) helps identify relatively underpriced or overpriced property that is eliminated from other distributions. Table II as it is shown helps in the design of edit routines that refine publicly recorded data. Thus Table II, which is printed for all coded property types, represents an important addition to the analytical tables available to the investigator.

Since property tax records include the date of construction, real estate sales for improved properties may be classified by age intervals. An example of these sales for single family dwellings is reproduced in Table III. In a growth community, such a series shows the porportion of the market satisfied by new construction. Though the table calls for the total sales for the first three years, most of these transactions would represent new housing. In this case, ober one third of the single family dwellings in 1968 were apparently satisfied by relatively new construction. Furthermore, the value of this table tends to be increased as comparisons are made over succeeding years. It will be notedalso that new houses tend to be relatively overassessed compared to older dwellings. Students of the filtering process may draw other conclusions from this table. Further classification of dwelling prices by age intervals, value groups, and location would give an important insight into the local housing filtering process.

The frequency tables arranged by assessment ratio intervals of two percent indicate the degree of uniformity or nonuniformity of assessed values. In addition, these distributions cast doubt over urban studies that rely on assessedvalues as a data source. The latter are often used to measure urbangrowthtrends or the effect of transportation changes on housing or other urban series. Tables for each property type indicate that such studies must be interpreted with caution largely because of the relatively high degree of dispersion between and among individual assessments. 
TABLE II - AVERAGE ASSESSMENT RATIOS OF CONDOMINIUMS CLASSIFIED BY SALES VALUE INTERVALS OF $\$ 2,000$

\begin{tabular}{|c|c|c|c|c|c|}
\hline $\begin{array}{c}\text { Sales } \\
\text { Value } \\
\text { Intervals }\end{array}$ & $\begin{array}{c}\text { Number } \\
\text { of } \\
\text { Sales } \\
\end{array}$ & $\begin{array}{l}\text { Percent } \\
\text { of Total } \\
\text { Number }\end{array}$ & $\begin{array}{l}\text { Sales Value } \\
\text { of Property } \\
\text { Represented }\end{array}$ & $\begin{array}{c}\text { Percent } \\
\text { of Total } \\
\text { Sales Value } \\
\end{array}$ & $\begin{array}{c}\text { Average } \\
\text { Assessment } \\
\text { Ratio } \\
\end{array}$ \\
\hline $1-2,000$ & 0 & 0.0 & 0 & 0.0 & 0.0 \\
\hline $2,001-4,000$ & 0 & 0.0 & 0 & 0.0 & 0.0 \\
\hline $4,001-6,000$ & 9 & 0.3 & 55,433 & 0.1 & 146.6 \\
\hline $6,001-8,000$ & 90 & 2.6 & 753,649 & 1.2 & 85.7 \\
\hline $8,001-10,000$ & 293 & 8.3 & $2,951,033$ & 4.5 & 80.0 \\
\hline $10,000-12,000$ & 482 & 13.7 & $5,736,882$ & 8.8 & 79.5 \\
\hline $12,001-14,000$ & 620 & 17.6 & $8,572,283$ & 13.1 & 80.4 \\
\hline $14,001-16,000$ & 496 & 14.1 & $7,896,648$ & 12.1 & 82.1 \\
\hline $16,001-18,000$ & 393 & 11.2 & $6,988,716$ & 10.7 & 81.2 \\
\hline $18,001-20,000$ & 230 & 6.5 & $4,568,599$ & 7.0 & 82.1 \\
\hline $20,001-22,000$ & 191 & 5.4 & $4,173,316$ & 6.4 & 80.8 \\
\hline $22,001-24,000$ & 154 & 4.4 & $3,684,832$ & 5.6 & 85.2 \\
\hline $24,001-26,000$ & 139 & 3.9 & $3,590,650$ & 5.5 & 80.8 \\
\hline $26,001-28,000$ & 73 & 2.1 & $2,025,900$ & 3.1 & 77.5 \\
\hline $28,001-30,000$ & 37 & 1.1 & $1,102,100$ & 1.7 & 77.0 \\
\hline $30,001-32,000$ & 34 & 1.0 & $1,081,800$ & 1.7 & 75.2 \\
\hline $32,001-34,000$ & 31 & 0.9 & $1,041,866$ & 1.6 & 75.9 \\
\hline $34,001-36,000$ & 47 & 1.3 & $1,688,266$ & 2.6 & 79.8 \\
\hline $36,001-38,000$ & 47 & 1.3 & $1,778,649$ & 2.7 & 82.2 \\
\hline $38,001-40,000$ & 39 & 1.1 & $1,552,500$ & 2.4 & 81.6 \\
\hline $40,001-42,000$ & 20 & 0.6 & 830,900 & 1.3 & 78.0 \\
\hline $42,001-44,000$ & 5 & 0.1 & 218,700 & 0.3 & 82.0 \\
\hline $44,001-46,000$ & 13 & 0.4 & 592,000 & 0.9 & 70.1 \\
\hline $46,001-48,000$ & 6 & 0.2 & 285,800 & 0.4 & 90.2 \\
\hline $48,001-50,000$ & 9 & 0.3 & 448,300 & 0.7 & 86.7 \\
\hline $50,001-52,000$ & 11 & 0.3 & 571,900 & 0.9 & 84.7 \\
\hline $52,001-54,000$ & 11 & 0.3 & 591,200 & 0.9 & 82.5 \\
\hline $54,001-56,000$ & 14 & 0.4 & 779,500 & 1.2 & 85.6 \\
\hline $56,001-58,000$ & 7 & 0.2 & 403,300 & 0.6 & 85.7 \\
\hline $58,001-60,000$ & 5 & 0.1 & 299,000 & 0.5 & 65.4 \\
\hline $60,001-62,000$ & 3 & 0.1 & 187,000 & 0.3 & 56.6 \\
\hline $62,001-64,000$ & 0 & 0.0 & 0 & 0.0 & 0.0 \\
\hline $64,001-66,000$ & 3 & 0.1 & 195,000 & 0.3 & 60.6 \\
\hline $66,001-68,000$ & 2 & 0.1 & 135,000 & 0.2 & 80.0 \\
\hline $68,001-70,000$ & 0 & 0.0 & 0 & 0.0 & 0.0 \\
\hline $70,001-72,000$ & 0 & 0.0 & 0 & 0.0 & 0.0 \\
\hline $72,001-74,000$ & 1 & 0.0 & 74,000 & 0.1 & 74.1 \\
\hline $74,001-76,000$ & 2 & 0.1 & 150,000 & 0.2 & 64.4 \\
\hline $76,001-78,000$ & 0 & 0.0 & 0 & 0.0 & 0.0 \\
\hline 78,001 and over ${ }^{1}$ & 3 & 0.1 & 258,300 & 0.3 & 69.9 \\
\hline Totals & 3,520 & 100.0 & $65,252,112$ & 100.0 & \\
\hline
\end{tabular}

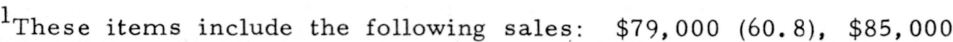
(61.6), and $\$ 93,000(87.2)$. 
TABLE III - AVERAGE ASSESSMENT RATIOS OF SINGLE FAMILY DWELLINGS CLASSIFIED BY ESTIMATED AGE INTERVALS

\begin{tabular}{|c|c|c|c|c|c|}
\hline $\begin{array}{c}\text { Estimated } \\
\text { Age } \\
\end{array}$ & $\begin{array}{c}\text { Number } \\
\text { of } \\
\text { Sales } \\
\end{array}$ & $\begin{array}{l}\text { Percent } \\
\text { of Total } \\
\text { Number }\end{array}$ & $\begin{array}{l}\text { Sales Value } \\
\text { of Property } \\
\text { Represented }\end{array}$ & $\begin{array}{c}\text { Percent } \\
\text { of Total } \\
\text { Sales Value } \\
\end{array}$ & $\begin{array}{c}\text { Average } \\
\text { Assessment } \\
\text { Ratio } \\
\end{array}$ \\
\hline $1-2.9$ & 5,017 & 34.5 & $\$ 104,594,608$ & 36.9 & 86.3 \\
\hline $3-4.9$ & 673 & 4.6 & $17,228,064$ & 6.1 & 75.6 \\
\hline $5-6.9$ & 827 & 5.7 & $19,554,352$ & 6.9 & 75.3 \\
\hline $7-8.9$ & 1,300 & 9.0 & $25,952,336$ & 9.2 & 74.9 \\
\hline $9-10.9$ & 1,984 & 13.7 & $34,183,936$ & 12.1 & 74.9 \\
\hline $11-12.9$ & 1,771 & 12.2 & $30,945,088$ & 10.9 & 72.7 \\
\hline $13-14.9$ & 1,230 & 8.5 & $20,522,864$ & 7.2 & 70.6 \\
\hline $15-16.9$ & 731 & 5.0 & $12,105,080$ & 4.3 & 72.6 \\
\hline $17-18.9$ & 596 & 4.1 & $11,257,181$ & 4.0 & 72.4 \\
\hline $19-20.0$ & 38 & 0.3 & 811,700 & 4.3 & 75.0 \\
\hline $21-22.9$ & 82 & 0.6 & $1,214,033$ & 0.4 & 69.4 \\
\hline $23-24.9$ & 53 & 0.4 & 755,000 & 0.3 & 74.1 \\
\hline $25-26.9$ & 53 & 0.4 & $1,352,100$ & 0.5 & 75.4 \\
\hline $27-28.9$ & 19 & 0.1 & 353,800 & 0.1 & 68.3 \\
\hline $29-30.9$ & 58 & 0.4 & $1,204,116$ & 0.4 & 73.2 \\
\hline $31-32.9$ & 9 & 0.1 & 186,400 & 0.1 & 58.6 \\
\hline $33-34.9$ & 57 & 0.4 & 736,500 & 0.3 & 69.5 \\
\hline $35-36.9$ & 4 & 0.0 & 66,800 & 0.0 & 104.7 \\
\hline $37-38.9$ & 8 & 0.1 & 83,000 & 0.0 & 85.8 \\
\hline $39-40.9$ & 6 & 0.0 & 288,800 & 0.1 & 79.1 \\
\hline $41-42.9$ & 0 & 0.0 & 0 & 0.0 & 0.0 \\
\hline $43-44.9$ & 7 & 0.0 & 71,300 & 0.0 & 59.4 \\
\hline $45-46.9$ & 0 & 0.0 & 0 & 0.0 & 0.0 \\
\hline $47-48.9$ & 0 & 0.0 & 0 & 0.0 & 0.0 \\
\hline $49-50.9$ & 1 & 0.0 & 13,000 & 0.0 & 62.6 \\
\hline Totals & 14,524 & 100.0 & $\$ 283,343,616$ & 100.0 & 79.5 \\
\hline
\end{tabular}

Table IV is an example of assessment ratio interval tables for single family dwellings. The arithmetic mean, or the average percent of assessed value to sales value for 14,601 observations, was some 78.6 percent. Approximately the first quartile of sales were assessed at a value of less than 68. 0 percent of the sales price. Approximately one half of the 1968 single family dwelling sales were assessed between 68.0 and 86.0 of the sales price. Another 26.7 percent of the observations were assessed over 88.0 percent of the sales price. Generally the dispersion of assessed values between and among individual properties was much higher for other property types. Thus regional models that rely on assessed values or census data purporting to measure the degree of central tendency for property tax assessments should be interpreted with care.

One purpose of this investigation was to statistically refine recorded and other public data to show trends in property values. Note that in Table IV, sales of $\$ 2,000$ or less were recorded for assessment ratio intervals beginning with $8.0,16.0$, and 28.0 percent. Investigation disclosed that these values constituted coding errors in the property tax records. Later routines corrected for these discrepancies by omitting single family dwelling sales of less than $\$ 6,000$. Thus by introducing editing routines, it is believed feasible to refine public records to interpret real estate sales data without expensive, time consuming, and personal sales verification. 
TABLE IV - THE RANGE OF ASSESSMENTS BY INTERVALS OF TWO PERCENT: SINGLE FAMILY DWELLINGS ${ }^{1}$

\begin{tabular}{|c|c|c|c|c|}
\hline $\begin{array}{c}\text { Assessment } \\
\text { Ratio } \\
\text { Intervals } \\
\end{array}$ & $\begin{array}{c}\text { Number } \\
\text { of } \\
\text { Sales }\end{array}$ & $\begin{array}{l}\text { Percent } \\
\text { of Total } \\
\text { Number }\end{array}$ & $\begin{array}{l}\text { Sales Value } \\
\text { of Property } \\
\text { Represented }\end{array}$ & $\begin{array}{c}\text { Percent } \\
\text { of Total } \\
\text { Sales Value } \\
\end{array}$ \\
\hline $0.1-1.9$ & 0 & 0.0 & $\$ \quad 0$ & 0.0 \\
\hline $2.0-3.9$ & 0 & 0.0 & 0 & 0.0 \\
\hline $4.0-5.9$ & 0 & 0.0 & 0 & 0.0 \\
\hline $6.0-7.9$ & 0 & 0.0 & 0 & 0.0 \\
\hline $8.0-9.9$ & 1 & 0.0 & 800 & 0.0 \\
\hline $10.0-11.9$ & 0 & 0.0 & 0 & 0.0 \\
\hline $12.0-13.0$ & 1 & 0.0 & 45,000 & 0.0 \\
\hline $14.0-15.9$ & 0 & 0.0 & 0 & 0.0 \\
\hline $16.0-17.9$ & 1 & 0.0 & 2,000 & 0.0 \\
\hline $18.0-19.9$ & 0 & 0.0 & 0 & 0.0 \\
\hline $20.0-21.9$ & 0 & 0.0 & 0 & 0.0 \\
\hline $22.0-23.9$ & 3 & 0.0 & 250,000 & 0.1 \\
\hline $24.0-25.9$ & 1 & 0.0 & 148,000 & 0.1 \\
\hline $26.0-27.9$ & 1 & 0.0 & 75,000 & 0.0 \\
\hline $28.0-29.9$ & 1 & 0.0 & 1,300 & 0.0 \\
\hline $30.0-31.9$ & 3 & 0.0 & 28,600 & 0.0 \\
\hline $32.0-33.9$ & 3 & 0.0 & 20,033 & 0.0 \\
\hline $34.0-35.9$ & 2 & 0.0 & 46,000 & 0.0 \\
\hline $36.0-37.9$ & 1 & 0.0 & 16,000 & 0.0 \\
\hline $38.0-39.9$ & 8 & 0.1 & 271,000 & 0.1 \\
\hline $40.0-41.9$ & 9 & 0.1 & 351,000 & 0.1 \\
\hline $42.0-43.9$ & 11 & 0.1 & 165,900 & 0.1 \\
\hline $44.0-45.9$ & 15 & 0.1 & 464,500 & 0.2 \\
\hline $46.0-47.9$ & 22 & 0.2 & 553,633 & 0.2 \\
\hline $48.0-49.9$ & 47 & 0.3 & 994,433 & 0.4 \\
\hline $50.0-51.9$ & 55 & 0.4 & $1,943,800$ & 0.7 \\
\hline $52.0-53.9$ & 114 & 0.8 & $2,551,249$ & 0.9 \\
\hline $54.0-55.9$ & 161 & 1.1 & $3,589,849$ & 1.3 \\
\hline $56.0-57.9$ & 255 & 1.7 & $5,047,249$ & 1.8 \\
\hline $58.0-59.9$ & 369 & 2.5 & $7,875,949$ & 2.8 \\
\hline $60.0-61.9$ & 475 & 3.3 & $8,980,814$ & 3.2 \\
\hline $62.0-63.9$ & 596 & 4.1 & $11,972,366$ & 4.2 \\
\hline $64.0-65.9$ & 708 & 4.8 & $14,015,914$ & 4.9 \\
\hline $66.0-67.9$ & 752 & 5.2 & $15,036,147$ & 5.3 \\
\hline $68.0-69.9$ & 795 & 5.4 & $15,906,763$ & 5.6 \\
\hline $70.0-71.9$ & 838 & 5.7 & $16,493,864$ & 5.8 \\
\hline $72.0-73.9$ & 816 & 5.8 & $17,173,328$ & 6.1 \\
\hline $74.0-75.9$ & 820 & 5.6 & $16,942,400$ & 6.0 \\
\hline $76.0-77.9$ & 820 & 5.6 & $16,810,000$ & 5.9 \\
\hline $78.0-79.9$ & 767 & 5.3 & $16,133,781$ & 5.7 \\
\hline $80.0-81.9$ & 764 & 5.2 & $15,841,630$ & 5.6 \\
\hline $82.0-83.9$ & 775 & 5.3 & $15,684,465$ & 5.5 \\
\hline $84.0-85.9$ & 676 & 4.6 & $12,985,832$ & 4.6 \\
\hline $86.0-87.9$ & 707 & 4.8 & $12,744,314$ & 4.5 \\
\hline $88.0-89.9$ & 553 & 3.8 & $10,476,950$ & 3.7 \\
\hline $90.0-91.9$ & 495 & 3.4 & $9,017,499$ & 3.2 \\
\hline $92.0-93.9$ & 433 & 3.0 & $7,626,665$ & 2.7 \\
\hline $94.0-95.9$ & 356 & 2.4 & $6,093,299$ & 2.1 \\
\hline $96.0-97.9$ & 312 & 2.1 & $5,381,498$ & 1.9 \\
\hline $98.0-99.9$ & 221 & 1.4 & $3,590,765$ & 1.3 \\
\hline 100 and over & 808 & 5.5 & $10,357,556$ & 3.7 \\
\hline Totals & 14,601 & 100.0 & $\$ 283,576,064$ & 100.0 \\
\hline
\end{tabular}

$1_{\text {The sales in this group are listed by their property tax number, sales }}$ value, and assessment ratio. The number of items precludes their publication here. 
To help determine the status of assessed values and to help identify common neighborhood zones for valuation purposes, statistical tables were prepared for the sample of 23,883 sales for each property type. Table V indicates the statistical summary applying to the entire sample. The computer program is such that Table $\mathrm{V}$ may be reproduced for all transactions for every property type or for each property type stratified further by townships, sections, or other divisions.

TABLE V - STA TISTICAL SUMMARY OF 1968 REAL ESTATE SALES ${ }^{1}$ Item Statistical Value

Number of Sales

Average Assessment Ratio

Mean Deviation

Coefficient of Dispersion

Lowest Assessment Ratio

Highest Assessment Ratio
23,883

78.6 percent

15.5

19. 7

0.6

950.0

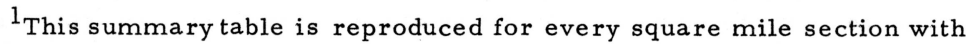
more than six sales for single family dwellings. Sales of less than $\$ 6,000$ have been omitted. The table may also be printed for other property types.

Note that the statistical summary tables provide a quick measure of the relative assessment uniformity for each distribution. The coefficient of dispersion is the mean deviation expressed as a percent of the average assessment ratio. This procedure corrects for the tendency of mean deviations to decrease with relatively low measures of central tendency. The range of assessment ratios gives anothe $r$ indication of relative assessment uniformity. In other distributions, these extremes are printed for possible field investigation by the assessing staff.

\section{Neighborhood Analysis}

TABLE VI - SALES ANALYSIS OF SINGLE FAMILY DWELLINGS BY SECTION, TOWNSHIP, AND RANGE: SECTION REPORT ${ }^{1}$

\begin{tabular}{ll}
\hline \multicolumn{1}{c}{ Item } & \multicolumn{1}{c}{ Statistical Value } \\
\hline Section Code & 504111 \\
Number of Sales & 176 \\
Total Sales Price & $\$ 4,374,250$ \\
Mean Sales Price & $\$ \quad 24,854$ \\
Standard Deviation & $\$ \quad 6,136$ \\
Minimum Sales Price & $\$ \quad 13,740$ \\
Maximum Sales Price & $\$ \quad 41,460$ \\
Modal Price & $\$ \quad 26,500$ \\
\hline
\end{tabular}

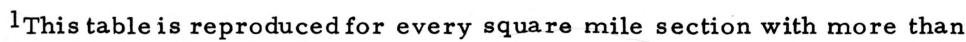
six sales. For single family dwellings, sales of less than $\$ 6,000$ have been omitted. The table is also printed for other property types. 
Primarily to guide the selection of multiple regression samples (multiple regression models were used to predict values for numerous subsets), it seemed worthwhile, initially, to stratify the sales sample by square miles: section, township, and range. See Table VI for a typical distribution.

The section code shown in Table VI refers to section 11, township 50, range 41 east of the Tallahassee meridian. The first purpose of this distributionwas to reveal the relative degree of homogeneity among single family neighborhoods as indicated by sales value. Note that for the 176 sales of Table VI, the mean sales price was some $\$ 24,854$ with a standard deviation of $\$ 6,136$. Prices ranged from $\$ 16,740$ to a high of $\$ 41,460$. In addition, the computer program arranged data by $\$ 1,000$ intervals and reported the mid value of the modal interval, which in this case is $\$ 26,500$. Thus the investigator has descriptive statistics on sales of coded property types. These distributions may also be made for other properties.

An additional insight into urban trends in single family dwellings is provided by a tabulation of dwelling sales by sections or square miles ranked to indicate the mean sales price classified by $\$ 1,000$ intervals. See Table VII. In this table the modal interval shows a mean sales price falling between $\$ 11,000$ and $\$ 11,999$ in 21 sections--which accounts for 1,187 dwelling sales (Table VII shows a higher number of sales compared to Table IV because some data of Table IV were omitted in cases of mergers and segregations that did not allow a matching of the sales price with the appropriate assessed values). As data for succeeding years are subjected to the same tabulation, the planner and others have a precise measure of residential and community growth for fairly small areas.

To show the arrangement of single family dwellings, graphically, classified by value, sections (a square mile) were identified according to the mean sales price that fell within the following groups:

$$
\begin{aligned}
& \frac{\text { Mean }}{\$} \frac{\text { Sales }}{0-\$ 1} \frac{\text { Price }}{0,000} \\
& \$ 10,001-\$ 12,000 \\
& \$ 12,001-\$ 14,000 \\
& \$ 14,001-\$ 16,000 \\
& \$ 16,001-\$ 18,000 \\
& \$ 18,001-\$ 20,000 \\
& \$ 20,001-\$ 22,000 \\
& \$ 22,001-\$ 24,000 \\
& \$ 24,000 \text { and over }
\end{aligned}
$$

Classifying dwelling sales in this manner revealed broad neighborhood patterns. Generally, high-valued property was concentrated within a one-mile stripeast of the beach frontage (the Atlantic Ocean) while low valued property centered five miles eastward paralleling ocean frontage and the main northsouth traffic routes. The development of more outlying communities around an urban complex showed the development of satellite communities, generally seven to tenmiles east of the beach area and favored with close access from the Sunshine State Parkway (a toll road). As data for succeeding years are classified in this way, definite neighborhood trends, growth patterns, declining neighborhoods will be clearly identified. Plans are underway to correlate sales prices with census tracts to improve usefulness of locational data. 
TABLE VII - THE DISTRIBUTIONOF 1968 DWELLING SALES BY SECTION, TOWNSHIP, AND RANGE: BROWARD COUNTY, FLORIDA

\begin{tabular}{|c|c|c|c|c|}
\hline Sales Price & $\begin{array}{c}\text { Number } \\
\text { of } \\
\text { Sections }\end{array}$ & $\begin{array}{l}\text { Percent } \\
\text { of Total } \\
\text { Number }\end{array}$ & $\begin{array}{c}\text { Number of } \\
\text { Dwelling } \\
\text { Sales }\end{array}$ & $\begin{array}{l}\text { Percent } \\
\text { of Total } \\
\text { Number } \\
\end{array}$ \\
\hline $\begin{array}{r}\$ 6,000-6,999 \\
7,000-7,999 \\
8,000-8,999 \\
9,000-9,999\end{array}$ & $\begin{array}{r}3 \\
5 \\
10 \\
12\end{array}$ & $\begin{array}{l}2.0 \\
3.3 \\
6.6 \\
7.9\end{array}$ & $\begin{array}{r}62 \\
277 \\
1,042 \\
1,465\end{array}$ & $\begin{array}{r}.4 \\
1.9 \\
7.0 \\
9.8\end{array}$ \\
\hline $\begin{array}{l}10,000-10,999 \\
11,000-11,999 \\
12,000-12,999 \\
13,000-13,999\end{array}$ & $\begin{array}{r}13 \\
21 \\
12 \\
7\end{array}$ & $\begin{array}{r}8.6 \\
13.8 \\
7.9 \\
4.6\end{array}$ & $\begin{array}{r}1,182 \\
1,887 \\
1,178 \\
582\end{array}$ & $\begin{array}{r}7.9 \\
12.7 \\
7.9 \\
3.9\end{array}$ \\
\hline $\begin{array}{l}14,000-14,999 \\
15,000-15,999 \\
16,000-16,999 \\
17,000-17,999\end{array}$ & $\begin{array}{r}12 \\
8 \\
4 \\
3\end{array}$ & $\begin{array}{l}7.9 \\
5.3 \\
2.6 \\
2.0\end{array}$ & $\begin{array}{r}1,637 \\
746 \\
780 \\
224\end{array}$ & $\begin{array}{r}11.0 \\
5.0 \\
5.2 \\
1.5\end{array}$ \\
\hline $\begin{array}{l}18,000-18,999 \\
19,000-19,999 \\
20,000-20,999 \\
21,000-21,999\end{array}$ & $\begin{array}{l}5 \\
3 \\
3 \\
4\end{array}$ & $\begin{array}{l}3.3 \\
2.0 \\
2.0 \\
2.6\end{array}$ & $\begin{array}{r}342 \\
280 \\
179 \\
1,043\end{array}$ & $\begin{array}{l}2.3 \\
1.9 \\
1.2 \\
7.0\end{array}$ \\
\hline $\begin{array}{l}22,000-22,999 \\
23,000-23,999 \\
24,000-24,999 \\
25,000-25,999\end{array}$ & $\begin{array}{l}2 \\
4 \\
8 \\
-\end{array}$ & $\begin{array}{l}1.3 \\
2.6 \\
5.3 \\
-\end{array}$ & $\begin{array}{c}173 \\
352 \\
584 \\
-\end{array}$ & $\begin{array}{l}1.2 \\
2.4 \\
3.9 \\
-\end{array}$ \\
\hline $\begin{array}{l}26,000-26,999 \\
27,000-27,999 \\
28,000-28,999 \\
29,000-29,999\end{array}$ & $\begin{array}{l}1 \\
1 \\
2 \\
0\end{array}$ & $\begin{array}{r}.7 \\
.7 \\
1.3 \\
0.0\end{array}$ & $\begin{array}{r}24 \\
46 \\
219 \\
0\end{array}$ & $\begin{array}{r}.2 \\
.3 \\
1.5 \\
0.0\end{array}$ \\
\hline $\begin{array}{l}30,000-30,999 \\
31,000-31,999 \\
32,000-32,999 \\
33,000-33,999\end{array}$ & $\begin{array}{l}1 \\
1 \\
2 \\
1\end{array}$ & $\begin{array}{l}.7 \\
.7 \\
1.3 \\
.7\end{array}$ & $\begin{array}{r}161 \\
22 \\
92 \\
66\end{array}$ & $\begin{array}{r}1.1 \\
.1 \\
.6 \\
.4\end{array}$ \\
\hline 34,000 and over & 4 & 2.6 & 266 & 1.8 \\
\hline Total & 152 & 100.0 & 14,911 & 100.0 \\
\hline
\end{tabular}

Neighborhood Delineation by Demographic Data: Discriminatory Analysis

Since many policy issues turn on the definition of neighborhoods, their boundaries, and characteristics, sales data were related to household income, pre capita income, and household size. Other literature report a positive correlation between incomes and dwelling values. Housing subsidies, planning policy, and mortgage practices are often based on the presumed relationship between dwelling values and income data.

\section{Discriminatory Analysis and the Discriminant Function}

The technique used in this paper (see Appendix A for mathematical detail) is a multivariate statistical method developed primarily as a classificatory measure. The assumptions surrounding the linear discriminant function are: 
(1) Some form of classes must exist or be as sumed to exist;

(2) Individual observations to be classified must belong to either of the groups or calibration samples.

The discriminant function is designed to maximize the ratio of distance between sample means of groups and the standard error within the sample. In this paper, the set of functions were used to discriminant between five groups of observations measuring three variables for all groups. Thus discriminatory analysis tested for significant different neighborhoods and then determined the probability of the placement of each sample area into any of the five neighborhood types.

$\underline{\text { Data }}$

The data were handled in the following manner.

(1) The mean prices of single family dwellings were classified by some 60 sections (square miles) covering the central portion of Fort Lauderdale.

(2) The sections were then grouped into sales price intervals:

$$
\begin{aligned}
& \$ 0-\$ 10,000 \text { per unit } \\
& \$ 10,001-\$ 14,000 \text { per unit } \\
& \$ 14,001-\$ 18,000 \text { per unit } \\
& \$ 18,001-\$ 22,000 \text { per unit } \\
& \$ 22,000 \text { and over }
\end{aligned}
$$

(3) All sections that fell into each interval were considered as one group or neighborhood type.

(4) The three variables, household income, per capita income, and household size (1963) were calculated for the five sales value groups.

(5) Next household income, per capita income, and household size and mean sales value by sections were grouped into five neighborhood groups as defined by Broward County Area Planning Board. The neighborhood groups accounted for the 60 sections identified for this study.

\section{Conclusions}

The statistic used to test the hypothesis that the means of the variables for each group were significantly different was the chi-square test. The statistic normally used to test significance in discriminatory analysis is the Generalized Mahalanobis D-Square statistic. Under an assumption of normality, however, the D-Square statistic can be interpreted as chi-square, using the same number of degrees of freedom. At the .01 alpha level, with 12 degrees of freedom, any computed value for chi-square of 26.217 or more suggests a variation greater than that which would result from random disturbance or chance. The actual computed D-Square value (or in this case the chi-square value) was 50.467. Therefore, we can assume that the variation of means among groups was statistically significant. This means that there are five distinct neighborhood groups as defined in this study.

Given discrete neighborhoods, it seemed worthwhile to investigate characteristics of each group to test for possible misclassification. Table VIII indicates the probability of misclassifying a planning neighborhood area as neighborhood five. That is, the table shows the method of calculating the 
probability that a single neighborhood planning area, among some 85 areas, would fall into one of the five sale value groups. These data a re calculated in the same way for each of the 85 neighborhood planning areas. Note that neighborhood planning area 16 logically belongs in sales value group five.

TABLE VIII - THE PROBABILITY OF CLASSIFYING A NEIGHBORHOOD PLANNING AREA INTO EACH OF THE FIVE SALE VALUE GROUPS

\begin{tabular}{l|c|c|c|c|c|c}
\hline \multicolumn{1}{c|}{ Sales Value Groups } \\
\cline { 3 - 6 } $\begin{array}{l}\text { Neighborhood Planning Area 16 } \\
\text { (From Sales Value Group 5) }\end{array}$ & .00916 & .04997 & .04383 & .08507 & .881197 \\
\hline
\end{tabular}

Table IX is a summary of the probabilities of misclassification. The most significant figures are those that extend diagonally from upper left to lower right. The figures on this diagonal show how many neighborhood planning areas should be classified with the original grouping. For example, reading across the first row of Group 1, of the original 13 observations, four should be classified in Group 1, i. e., 30.76 percent of Group 1 data are correctly classified. Of Group 2, note that eleven of the original observations should be classified with Group 2. The last column of Table IX shows the percentage of correct classifications within each group.

TABLE IX - A SUMMARY SHOWING THE RELATIVE CORRECTNESS OF NEIGHBORHOOD CLASSIFICATION ACCORDING TO MULTI-VARIANT ANALYSIS OF SALES VALUE GROUPS HOUSEHOLD INCOME, PER CAPITA INCOME, AND HOUSEHOLD SIZE

\begin{tabular}{|c|c|c|c|c|c|c|c|}
\hline \multirow[t]{2}{*}{$\begin{array}{c}\text { The Sales Value Group in } \\
\text { Which Each Neighborhood } \\
\text { Planning Area Falls }\end{array}$} & \multicolumn{5}{|c|}{$\begin{array}{l}\text { Sales } \\
\text { Value } \\
\text { Groups }\end{array}$} & \multirow[t]{2}{*}{$\begin{array}{c}\text { Total Number of } \\
\text { Neighborhood } \\
\text { Planning Areas } \\
\text { in Each of the } \\
\text { Five Sale Value } \\
\text { Groups }\end{array}$} & \multirow[t]{2}{*}{$\begin{array}{c}\text { Percent of } \\
\text { Classification } \\
\text { Within Each } \\
\text { Sales Value } \\
\text { Group }\end{array}$} \\
\hline & 1 & 2 & 3 & 4 & 5 & & \\
\hline Group 1 - Less than $\$ 10,000$ & 4 & 6 & 3 & 0 & 0 & 13 & 30.76 \\
\hline Group $2-\$ 10,000-\$ 13,999$ & 1 & 11 & 4 & 3 & 3 & 22 & 50.00 \\
\hline Group $3-\$ 14,000-\$ 17,999$ & 0 & 1 & 3 & 2 & 1 & 7 & 42.85 \\
\hline Group $4-\$ 18,000-\$ 21,999$ & 1 & 5 & 3 & 2 & 2 & 13 & 15.38 \\
\hline Group $5-\$ 22,000$ and over & 0 & 6 & 4 & 1 & 19 & 30 & 63.33 \\
\hline
\end{tabular}

In short the sales data as a means of defining neighborhoods is only partially valid. Using the $\mathrm{D}^{2}$ statistic we have identified significant differences among the five groups judged by household income, per capita income, and hous ehold size. Moreover, the re are apparently misclassifications within sale value groups suggesting that income and value of dwelling units do not necessarily correlate in the study area. This leads to the tentative proposition that in a rapidly growing urban area, the presumed relation between household income (and per capita income) and the value of dwellings does not always follow. A possible explanation of these relationships might turn on 
the fairly rapid transition in land use, new transportation routes, and changing population characteristics. Clearly these data would justify further study of urban growth patterns in rapidly expanding communities. 


\section{APPENDIX A}

The series of formulas presented here was used to calculate statistics for use in this paper.

1. The Data are in the form:

$\begin{aligned} & i=1,2, \ldots, g \\ x_{i j k} & =1,2, \ldots, g \\ k & =1,2, \ldots, g\end{aligned}$

where

$$
\begin{aligned}
& \mathrm{g}=\text { number of groups } \\
& \mathrm{n}_{\mathrm{i}}=\text { sample size of the } \mathrm{i}^{\text {th }} \text { group } \\
& \mathrm{m}=\text { number of variables }
\end{aligned}
$$

2. Means of variables considered within each group are computed.

$$
(x i 1, x i 2, \ldots, x i m), i=1,2, \ldots, g
$$

3. Matrix $S_{1}$, the sum of products of deviation from the mean is computed for each group.

$$
\begin{aligned}
\mathrm{S}_{\mathrm{i}}=\left(\mathrm{s}_{\mathrm{jk}}^{\mathrm{i}}\right) \quad \mathrm{j} & =1,2, \ldots, \mathrm{m} \\
\mathrm{k} & =1,2, \ldots, \mathrm{m}
\end{aligned}
$$

where

$$
s(j k)=\sum_{l=1}^{n_{i}}(x i l j-x i j)(x i l k-x i k)
$$

4. The pooled dispersion matrix $D$, based on the matrices $S_{1}, i=1,2, \ldots, g$ is computed.

$$
D=\frac{\sum_{i=1}^{g} S_{i}}{\sum_{i=1}^{g} n_{i}-g}
$$

5. Common means are then computed.

$$
x . . j=\left(\sum_{\ell=1}^{g} n l \times l j\right) /\left(\sum_{\ell=1}^{g} n \ell\right)
$$

6. The next computation is the calculation of the text statistic, the generalized Mahalanobis $\mathrm{D}^{2}$ statistic, v:

${ }^{1}$ W. J. Dixon, ed., BMD: Biomedical Computer Programs (University of California Press, 1968), pp. 200-01. 


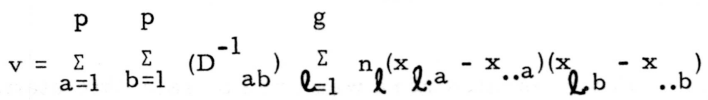

Under the assumption of normality the Generalized $\mathrm{D}^{2}$ can be used as chi-square, with $\mathrm{m}(\mathrm{g}-1)$ degrees of freedom, to test the hypothesis that the mean values are the same in all the groups for these $m$ variables.

7. The coefficients and constants are computed in the $i^{\text {th }}$ discriminatory function.

$$
i=1,2, \ldots, g
$$

Let $(\operatorname{dj} 1, d j 2, \ldots, d j m)$ be the $j^{\text {th }}$ row of $D^{-1}$.

Then coefficients, $C_{j i}=\sum_{\ell=1}^{m}$ djlxil

constant,

m $\mathrm{m}$

The $i *^{\text {th }}$ discriminating function is given by

$$
C_{\text {oi }}=-\frac{1}{2} \sum_{\ell=1} \sum_{r=1} d_{\ell r} x_{i} \cdot \ell x_{1} \cdot r
$$

$$
\mathrm{f}_{\mathrm{i}} *\left(\mathrm{z}_{1}, \mathrm{z}_{2}, \ldots, \mathrm{z}_{\mathrm{m}}\right)=\sum_{\ell=1}^{\sum} \mathrm{z}_{\ell} \mathrm{c}_{l_{\mathrm{i}} *}+\mathrm{c}_{\text {oi } *}
$$

8. The probability of the classification in each case in the $i *{ }^{\text {th }}$ group into each of the g groups is calculated by

$$
P i=\frac{e(f i *-\max . f i *)}{\sum e(f i *-\max . f i *)}
$$

9. Each observation is classified into the group for which the estimated probability density is greatest. 